\title{
Two grass herbicides for pineapple fields'
}

\author{
Li C. Liu and Nilsa M. Acin-Díaz
}

\begin{abstract}
Two field experiments (plant and ratoon crops) were conducted at Vega Baja and Barceloneta Land Authority pineapple farms in 1990 and 1991 to evaluate two grass herbicides. Fluazifop-p-butyl at 0.28 and $0.56 \mathrm{~kg}$ ai/ha and quizalofop at 0.224 and $0.448 \mathrm{ai} / \mathrm{ha}$ were applied postemergence twice to the 12 -month-old plant crop and twice to 30 -month-old ratoon pineapple plants. Two methods of application (over the top and directed spray) were used. Both herbicides gave excellent control of all grasses with no apparent crop injury. In the plant crop experiment, the highest fruit yield was obtained with quizalofop at $0.224 \mathrm{~kg}$ ai/ha applied over the top $(69,289 \mathrm{~kg} / \mathrm{ha})$. This treatment differed significantly in yield with three of the other herbicide treatments. In the ratoon crop experiment, the highest pineapple yield was obtained with fluazifop-p-butyl at $\mathbf{0 . 5 6}$ $\mathrm{kg}$ ai/ha applied as directed spray $(51,585 \mathrm{~kg} / \mathrm{ha})$. This treatment did not differ significantly with all other treatments.
\end{abstract}

\section{RESUMEN}

Dos graminicidas para piñales

En fincas de la Autoridad de Tierras en Vega Baja y Barceloneta se realizaron dos experimentos con herbicidas contra gramíneas en plantilla y retoño de piña de 1990 a 1991 . Se evaluó el fluazifop-p-butyl a razón de 0.28 y $0.56 \mathrm{~kg}$ ia/ha y el quizalofop a razón de 0.224 y $0.448 \mathrm{~kg} p / \mathrm{ha}$ en aspersiones sobre el follaje y dirigidas. Se realizaron dos aplicaciones posemergentes a una plantilla de 12 meses y dos aplicaciones a un retoño de $\mathbf{3 0}$ meses. Ambos herbicidas controlaron excelentemente las gramíneas sin que se observaran síntomas de fitotoxicidad. El rendimiento más alto de piñas en el experimento de plantilla se obtuvo con el quizalofop aplicado sobre el follaje a razón de $0.224 \mathrm{~kg}$ ia/ha $(69,289 \mathrm{~kg} / \mathrm{ha})$. Hubo diferencias significativas $(P=0.05)$ con tres de los otros tratamientos. En el experimento de refoño, el rendimiento mayor se obtuvo con el fluaxifopp-butyl en aplicación dirigida a razón de $0.56 \mathrm{pa} / \mathrm{ha}(51,585 \mathrm{~kg} / \mathrm{ha})$. No hubo diferencias significativas $(P=0.05)$ con los demás tratamientos.

\section{INTRODUCTION}

In 1990-91, 59,610 tons of pineapple fruits was produced in Puerto Rico with a farm value of $\$ 13.8$ million (2). High production costs have been one of the major factors limiting local pineapple production, and one

"Manuscript submitted to Editorial board 4 June 1992.

'Researcher, Department of Crop Protection.

'Associate Researcher, Department of Crop Protection. 
of the principal factors contributing to high production costs is the expense of weed control by manual labor (13). Early attempts to control weeds with eight oil fractions were made by Craft and Emmanueli (5). They found that light fraction stove naphtha could be used safely under greenhouse conditions. However, the stove naphtha injured mature pineapple plants under actual field conditions in Puerto Rico. They also tested a dinitro herbicide with little success because of crop injury (5). Cibes-Viade (3) reported that CMU (monuron) at 2, 4, and $6 \mathrm{lb} / \mathrm{A}(2.24$, 4.48 and $6.7 \mathrm{~kg} / \mathrm{ha}$ ) effectively controlled weeds in two field experiments in Manatí for a 3-month period. Subsequent trials found good selectivity of ametryn and diuron on pineapple plants (4). Paraquat and glyphosate were evaluated by González-Ibáñez (8), but registration of glyphosate for use in pineapple in Puerto Rico is still pending. Glyphosate was also reported by Deuse and Lavabre (6) to be highly effective against hard-tokill grasses in pineapple fields. Other good pineapple herbicides, such as bromacil and hexazinone, have also been evaluated $(6,7,12)$, but these herbicides are not as selective as ametryn and thus cause occasional crop injuries. Jordan and Omara (10) suggested that postemergence application of herbicides be avoided during the flower induction-to-harvest cycle of the pineapple plants because it could cause yield reduction.

The effectiveness of fluazifop has been reported by Horrelou (9). Fluazifop has been evaluated locally and found effective for grass control in tomatoes and peppers (11), also in coffee, sweet cherry peppers, yams, taniers and onions (unpublished results). Since grasses are the predominant weed species in local pineapple plantations, the registration of fluazifop-p-butyl or similar action herbicides (1) for pineapple will be beneficial to local growers. This paper reports efficacy, phytotoxicity and yield data from the evaluation of fluazifop-p-butyl $[+] 2[4-(6$-chloro-2quinoxaliniyl) oxyl phenoxyl propanoic acid in pineapple plant and ratoon crop.

\section{MATERIALS AND METHODS}

Plant crop experiment

The experiment was established October 1990 in a Bayamón silty clay (Clayey, oxidic isohyperthermic, Typic Haplorthox) on a Land Authority farm in Vega Baja, Puerto Rico. The top $15 \mathrm{~cm}$ of soil contained $0.8 \%$ organic matter with a pH of 4.9. A 12-month-old plant corp Red Spanish variety was chosen to determine efficacy, phytotoxicity and residue levels of fluazifop and quizalofop in pineapple. The individual plots consisted of approximately 100 pineapple plants in two beds $(2.85 \mathrm{~m}$ wide and $7.62 \mathrm{~m}$ long) separated by a $1.4-\mathrm{m}$ alley. Each bed contained two 0.6 $\mathrm{m}$-spaced double rows with $0.3 \mathrm{~m}$ between pineapple plants. Bromacil at $4.48 \mathrm{~kg} / \mathrm{ha}$ was applied pre-plant, followed by diuron at $4.48 \mathrm{~kg} / \mathrm{ha}$ one 
month after planting, and at $3.36 \mathrm{~kg} / \mathrm{ha}$ three months later. Eight different fluazifop and quizalofop treatments were replicated four times in a complete randomized block design. Two rates each of fluazifop and quizalofop were applied both over the top and directed spray. Fluazifop (FUSILADE) 4 at 0.28 and $0.58 \mathrm{~kg}$ ai/ha and quizalofop (ASSURE) at 0.224 and $0.448 \mathrm{~kg}$ ai/ha were applied twice (15 October and 30 October 1990) with a portable $\mathrm{CO}_{2}$ pressurized sprayer fitted with a four-nozzle broom at a spray volume of $367 \mathrm{~L} / \mathrm{ha}$ for the over-the-top application. A conventional knapsack sprayer fitted with a Teejet 8002 nozzle tip was used for the directed spray at a spray volume of $734 \mathrm{~L} / \mathrm{ha}$. (More water was necessary to obtain better coverage.) A surfactant X-77 was added to the final solution at $0.25 \%$ concentration. All agronomic and pest management followed recommended practices for pineapple cultivation in Puerto Rico. Weed control and phytotoxicity evaluations were made periodically. The mature pineapple fruits were harvested 7 April 1991 and the data analyzed statistically.

\section{Ratoon Crop Experiment}

The experiment was established on a farm located in Barceloneta, Puerto Rico, with the same soil type as that of the plant crop experiment. The top $15 \mathrm{~cm}$ of soil contained $1.3 \%$ organic matter with a $\mathrm{pH}$ of 5.5 . The first ratoon crop of a Red Spanish variety 30 -month-old plantation was chosen. The field received two diuron applications: at $4.48 \mathrm{~kg} / \mathrm{ha} 1$ month after ratooning, and a second postemergence at $3.36 \mathrm{~kg} / \mathrm{ha} 3$ months afterward. No pre-plant application of bromacil was made for this ratoon crop. The same plot size and experimental design as in the plant crop experiment were used. Fluazifop and quizalofop at the same rates were applied on two occasions (17 June and 2 July 1991). All agronomic and pest management followed the recommended practices for growing pineapple in Puerto Rico. Weed control and phytotoxicity evaluations were also made periodically. The mature pineapple fruits were harvested 17 December 1991.

\section{RESULTS AND DISCUSSION}

The predominant weed species at both experimental sites were Alexander grass (Brachiaria plantaginea), large crabgrass (Digitaria sanguinalis), radiate finger grass (Chloris radiata), sour grass (Trichachne insularis), guinea grass (Panicum maxium), jungle rice (Echinochloa

\footnotetext{
Trade names in this publication are used only to provide specific information. Mention of a trade name does not constitute a warranty of equipment or materials by the Agricultural Experiment Station of the University of Puerto Rico, nor is this mention a statement of preference over other equipment or materials.
} 
colona), garden spurge (Euphorbia heterophylla), morning glory (Ipomoea tiliacaae), pigweed (Amaranthus dubius), red tassel flower (Emilia sonchifolia), and purple nutsedge (Cyperus rotundus). Table 1 shows that an initial $90 \%$ control of practically all grasses was obtained

TABLE 1.-Weed control, phytotoxicity and fruit yield of pineapple as affected by two grass herbicides at Vega Baja farm.

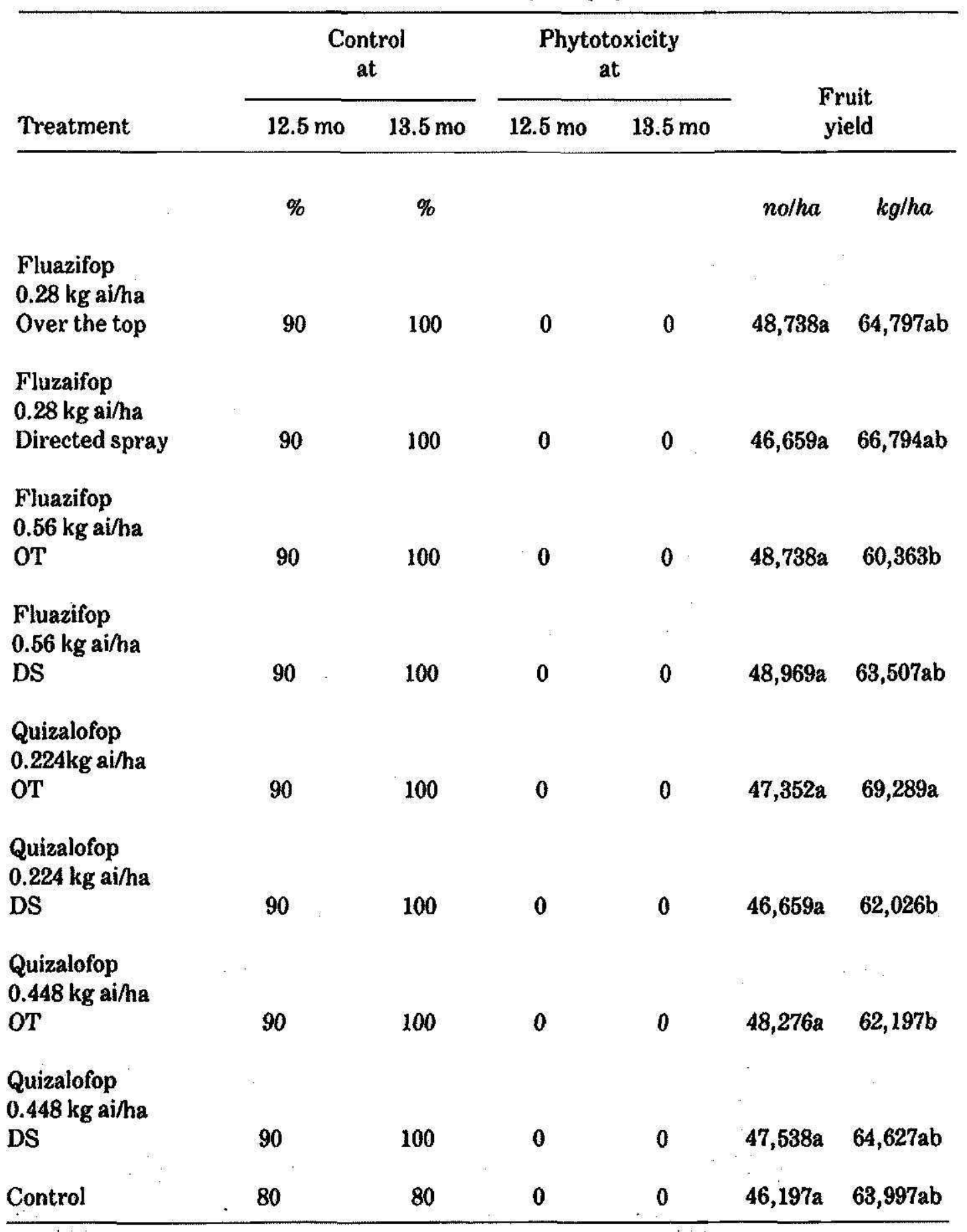

Weed control rating is based on a $0-100$ scale; $0=$ no control $100=$ perfect control.

${ }^{2}$ Phytotoxicity evaluation is based on a $0-5$ scale; $0=$ no crop injury, $5=$ completely killed.

Means followed by the same letters do not differ signifiantly at $P=0.05$. 
J. Agric. Univ. P.R. vol. 77, No. 1-2, JANUARY/APRIL, 199349

with both herbicides at all rates and methods of application. The control treatment, even though treated with neither fluazifop nor with quizalofop, did receive a pre-plant application of bromacil and two post-

TABLE 2.-Weed control, phylotoxicity and fruit yield of ratoon crop of pineapple as affected by two grass herbicides at Barceloneta.

\begin{tabular}{lllll}
\hline & \multicolumn{2}{c}{$\begin{array}{c}\text { Control } \\
\text { at }\end{array}$} & & \multicolumn{2}{c}{$\begin{array}{c}\text { Phytotoxicity } \\
\text { at }\end{array}$} & \\
\cline { 2 - 4 } Treatment & $31 \mathrm{mo}$ & $33 \mathrm{mo}$ & $31 \mathrm{mo} \quad 33 \mathrm{mo}$ & $\begin{array}{c}\text { Fruit } \\
\text { yield }\end{array}$ \\
\hline
\end{tabular}

$\% \quad$ nolha kg/ha

Fluazifop

$0.28 \mathrm{~kg}$ ai/ha

Over the top

100

95

0

0

$32,694 \mathrm{a} \quad 43,497 \mathrm{a}$

Fluzaifop

$0.28 \mathrm{~kg}$ ai/ha

Directed spray

100

95

0

0

$31,380 a \quad 45,292 a$

Fluazifop

$0.56 \mathrm{~kg}$ ai $/ \mathrm{ha}$

OT

100

95

0

0

$33,226 a \quad 42,536 a$

Fluazifop

$0.56 \mathrm{~kg}$ ai/ha

DS

100

95

0

0

$34,149 \mathrm{a} \quad 51,585 \mathrm{a}$

Quizalofop $0.224 \mathrm{~kg}$ ai/ha

OT

100

100

0

0

$36,457 a \quad 49,677 a$

Quizalofop $0.224 \mathrm{~kg}$ ai/ha DS 100 10

Quizalofop $0.448 \mathrm{~kg}$ ai/ha OT 100 100 0

0

$29,881 a \quad 39,523 a$

Quizalofop $0.448 \mathrm{~kg}$ ai $/ \mathrm{ha}$ DS 100 100 0

0
$34,034 a \quad 49,611 \mathrm{a}$

Control 85 80

0

0

$33,342 \mathrm{a} \quad 48,375 \mathrm{a}$

'Weed control rating is based on a $0-100$ seale; $0=$ no control $100=$ perfect control. 2Phytotoxicity evaluation is based on a $0-5$ scale; $0=$ no crop injury, $5=$ completely killed. Means followed by the same letters do not differ significantly at $\mathbf{P}=\mathbf{0 . 0 5}$. 
emergence applications of diuron as indicated in the materials and methods section. As a result of these applications, grass infestation at the time of the experimental herbicide treatments was not considered heavy. Neither herbicide caused any apparent pineapple injury, irrespective of the rate or method of application.

The highest plant crop fruit weight was obtained with quizalofop at $0.224 \mathrm{~kg}$ ai/ha over the top treatment $(69,289 \mathrm{~kg} / \mathrm{ha})$. This treatment did not differ significantly in yield with five other herbicide treatments (table 1) but was significantly higher than fluazifop at $0.56 \mathrm{~kg}$ ai/ha over the top, quizalofop at $0.224 \mathrm{~kg}$ ai/ha directed spray, and quizalofop at 0.448 $\mathrm{kg}$ ai/ha over the top treatment. Fluazifop at $0.56 \mathrm{~kg}$ ai/ha over the top treatment produced the lowest fruit yield $(60,363 \mathrm{~kg} / \mathrm{ha})$. There was no significant difference among different treatments with respect to the number of the fruits produced.

Table 2 shows the excellent weed control in the ratoon crop achieved by both herbicides, irrespective of the rate and method of application. There was no significant difference between all treatments in fruit number and weight (table 2). The highest ratoon crop yield was obtained with fluazifop at $0.56 \mathrm{~kg}$ ai/ha directed spray treatment $(51,585 \mathrm{~kg} / \mathrm{ha})$, and the lowest yield with quizalofop at $0.448 \mathrm{~kg}$ ai/ha over the top $(39,523$ $\mathrm{kg} / \mathrm{ha}$ ).

Neither fluazifop nor quizalofop has been registered with the Environmental Protection Agency (EPA) for use in pineapple in Puerto Rico. Until such registration is obtained, the use of either herbicide will constitute a violation of Federal and Puerto Rican law. Research continues, and data will be submitted to EPA through the IR-4 project for future registration of these products. One advantage of registering these highly selective herbicides is that their application could be made over the top of pineapple plants without any risk of crop injury. This will offer a viable alternative for postemergence and post treatment of problem weeds in pineapple fields.

\section{LITERATURE CITED}

1. Anon., 1983. Assure-experimental grasses herbicides (formerly DPX-6202) E. I. DuPont de Nemours \& Co., Inc. U.S.A. Technical Bulletin.

2. Anon., 1989. Ingreso Agrícola de Puerto Rico 1988-89. Departamento de Agricultura. Oficina de Estadisticas Agrícolas, Santurce, P.R.

3. Cibes-Viadé, H. R., 1957. Control of weeds in pineapple fields with CMU. J. Agric. Univ. P.R. 41(1):11-19.

4. - 1960-65. Annual Progress Report of Weed Control Project in Pineapple. Agric. Exp. Sta. Univ. P.R.

5. Crafts, A. S. and A. Emmanueli, 1948. Some experiments with herbicides in pineapple. Bot. Gaz. 110(2):313-18.

6. Deuse, J. C. et E. M. Lavabre, 1979. Le desherbage des cultures sous les tropiques. Technique agricolaes et productions tropoles. 
7. Gaillard, J. P., 1971. Le lutte contre Cyperus rotundus en culture d'ananas. Fruits 26(11):751-56.

8. González-Ibáñez, J. 1980-85. Annual Progress of Project H-173 (weed control in pineapple). Agric. Exp. Sta. Univ. P.R.

9. Horrellou, A., 1981. Un nouvelantigramineas selectif des cultures dicotyledones: le fluazifop butyl. Journes Etudes Desherbage 11th Conf. COLUMA.

10. Jordan, A. and R. Omara, 1976. Weed Control in Pineapple. Australian Weed Control Handbook. 3rd. Ed. 49-52.

11. Liu, C. and M. R. Goyal, 1989. Selective herbicides to control grass weeds in transplanted tomatoes and peppers. J. Agric. Univ, P.R. 73(3):261-68.

12. Py Claude, J. J., L. Teisson and C. Teisson, 1987. The Pineapple: Cultivation and Uses. G. P. Maisonneuve et. Larose.

13. Rivera-Vélez, A. I., 1986. Contribución de los plaguicidas agrícolas a la producción de la pina de la Autoridad de Puerto Rico. Tesis Maestría Ciencias Departamento de Economia Agxícola y Socialogía Rural, UPR, Mayagüez. 